\title{
Specific agglutination of tanned red cells coated with a globulin fraction of an antithyroid serum by saline extracts of thyroid glands
}

\author{
IAN MacLEOD \\ From the Department of Pathology, King's College, Durham University
}

SYNOPSIS Experiments are described in which tanned red cells coated with a globulin fraction of human serum with a high titre of antibody to human thyroglobulin were agglutinated by saline extracts of human thyroid gland and thyroglobulin but not by other tissue extracts. It is suggested that the linkage is due to a specific antigen antibody reaction between cell-bound antithyroid antibody and thyroglobulin in solution.

Richter, Cua-Lim, and Rose (1962) showed that red blood cells coated with purified antibody by the bis-diazotised benzidine technique were agglutinated by solutions of the corresponding antigen but that red cells coated in the same way with globulin fractions of the antiserum were not. In the experiments to be described, tanned red blood cells coated with globulin precipitated from the sera of patients with very high levels of anti-thyroglobulin were agglutinated by saline extracts of thyroid gland.

\section{MATERIALS}

TISSUE EXTRACTS Human tissues obtained at operation or necropsy were washed in $0.9 \%$ saline to remove blood and homogenized with enough $0.9 \%$ saline to give a $20 \% \mathrm{w} / \mathrm{v}$ suspension. This was centrifuged several times at 3,500 r.p.m. for 30 minutes to remove fat and particulate matter and the supernatant stored at $-20^{\circ} \mathrm{C}$. Extracts of thyroid glands from thyrotoxic and euthyroid subjects, liver, kidney, spleen, joint tissue, heart muscle, and brain were made in this way. Similarly $20 \% \mathrm{v} / \mathrm{v}$ extracts of washed and packed human blood cells were made.

Thyroglobulin was prepared from the extract of thyroid gland by the method of Derrien, Michel, and Roche (1948).

SERUM GLOBULIN Sera were inactivated at $56^{\circ} \mathrm{C}$. for 30 minutes and absorbed with an equal volume of washed packed sheep cells for one hour at room temperature. One volume of a 1 in 5 dilution of serum in $0.9 \%$ saline was mixed with one volume of $2.5 \mathrm{M}$ ammonium sulphate in the cold $\left(2^{\circ}-5^{\circ} \mathrm{C}\right.$. $)$.

The precipitate was centrifuged, redissolved in the

original volume of $0.9 \%$ saline and reprecipitated twice with an equal volume of $2.4 \mathrm{M}$ ammonium sulphate and finally resuspended in the original volume of $0.9 \%$ saline. Stored at $-20^{\circ} \mathrm{C}$. the globulin showed no loss of activity for up to a year despite repeated thawing and freezing. Various concentrations of ammonium sulphate were tried; a final concentration of $1.2 \mathrm{M}$ gave the best yield without loss of activity. Globulins prepared in this way appeared as a single band in the gamma position on paper electrophoresis; those from sera with antithyroid antibody agglutinated tanned red cells coated with thyroglobulin.

RABBIT SERUM Normal rabbit serum, inactivated at $56^{\circ} \mathrm{C}$. for 30 minutes and absorbed with an equal volume of washed packed cells for one hour at room temperature, was stored in $2 \mathrm{ml}$. portions at $-20^{\circ} \mathrm{C}$.

BUFFERED SALINE Buffered saline was made up of equal parts of $0.9 \% \mathrm{Na} \mathrm{Cl}$ and $0.15 \mathrm{M}$ Sorenson's phosphate buffer for $p \mathrm{H} 7 \cdot 2$.

TANNIC ACID (MERCK, REAGENT GRADE) A $1 \% \mathrm{w} / \mathrm{v}$ stock solution in distilled water was kept without apparent deterioration for a year at $4^{\circ} \mathrm{C}$. A $1 / 300$ dilution of this in buffered saline (i.e., 1/30,000 tannic acid) was used to tan the cells.

SHEEP CELLS Sheep blood was collected into $1 \cdot 2$ vol. of Alsever's solution and stored at $4^{\circ} \mathrm{C}$. for up to 10 days.

\section{METHOD}

In early experiments the method of Boyden and Sorkin (1955) was used. In later experiments this was simplified, 
the whole process was carried out at $p \mathrm{H} 7 \cdot 2$ and the coating agent was added to the mixture of cells and tannic acid instead of to the washed and resuspended tanned cells. Adding the coating agent and tannic acid to the cells simultaneously did not work. Boyden found that coating with P.P.D. at $p \mathrm{H} 7.2$ resulted in non-specific agglutination, and that omitting the washing and resuspension between tanning and coating resulted in a reduction of agglutination titres. Neither of these difficulties was encountered with the antithyroid-thyroid extract system. The method in its final form was as follows. From sheep cells washed three times in about 10 volumes of $0.9 \%$ saline an approximately $30 \%$ suspension in $p \mathrm{H} 7 \cdot 2$ buffered saline was made. The packed cell volume was measured in a Hawksely micro-haematocrit and the suspension diluted to exactly $2 \%$. One volume of this was mixed with 1 volume of $1 / 30,000$ tannic acid and after 10 minutes at room temperature one volume of globulin dilution was added. After a further $\mathbf{1 0}$ minutes the cells were centrifuged (1,500 r.p.m. for 10 minutes) washed twice and resuspended in $0.9 \%$ saline containing $1 \%$ $\mathrm{w} / \mathrm{v}$ normal rabbit serum. Cells were tanned and coated with thyroglobulin in the same way, using sensitizing concentrations between 1 and $2 \mathrm{mg}$. $/ \mathrm{ml}$. The cells were resuspended to $1 \%$ for direct agglutination tests using 2 volumes or $1.5 \%$ for agglutination inhibition tests using 3 volumes; in each case the final concentration in the tube was $0.5 \%$. If more than a trace of haemolysis occurred during washing, the cell concentration was checked by measuring the haemoglobin content against a standard prepared from the original $2 \%$ suspension.

Serial two-fold dilutions of antigen solution were made in normal rabbit serum saline using a fresh pipette for each dilution and $0 \cdot 15 \mathrm{ml}$. of each was added to a row of $1 \frac{1}{8}$ in. $\times \frac{3}{16}$ in. Durham's tubes held at an angle of $45^{\circ}$ in a Perspex rack; $0.15 \mathrm{ml}$. of cell suspension was added to each tube (without the pipette touching the antigen solution) and mixed by gently shaking the rack. Transfers were made with a Pasteur pipette attached to a Colindale constant volume syringe.

Results were read after six hours at room temperature; $3+$ agglutination was recorded when all cells stuck to the side of the tube, $\mathrm{O}$ when all lay in a compact button at the bottom, while intermediate states were graded $2+, 1+$, or trace.

\section{CONTROLS}

The following controls were set up with each test:-

1 Tanned cells coated with normal rabbit serum saline instead of globulin; these were set up alone to check on auto-agglutination and with the tissue extract under test to show any non-specific agglutination.

2 Tanned cells coated with the globulin on test were set up with 1 volume of normal rabbit serum saline in place of the tissue extract as a further control on autoagglutination.

3 Known positive and negative reactions were set up with each batch of tests.

4 Coated cells were set up with mixtures of the tissue extract under test and the coating agent, as an 'inhibitor' control.
RESULTS

Globulin from 43 human sera were applied to cells in dilutions between $1 / 10$ and $1 / 10, \mathrm{CO}$ (all globulin $\bar{O}$ dilutions are expressed in terms of the parent $\overline{\bar{s}}$ serum); cells coated by eight of the globulins were agglutinated by extracts of thyroid gland but not by any other tissue extracts. In most cases agglutin- ${ }^{\infty}$ ation occurred only with the stronger sensitizing. concentrations $(1 / 10$ to $1 / 50)$ but one globulin was $\vec{A}$ active at a dilution of $1 / 640$. Cells coated with one of ${ }_{\sigma}^{\omega}$ the globulins produced $3+$ agglutination with dilutions of thyroid extract as high as $1 / 1,000,000$, with five of the others up to $1 / 25,000$, and with the two remaining to $1 / 5,000$. Coated cells were also tested with dilutions of thyroglobulin solution and $\frac{\infty}{\omega}$ $3+$ agglutination occurred at dilutions up too $1 / 500,000$. Since the stock solution contained $530 \mathrm{mg}$. of thyroglobulin $100 \mathrm{ml}$. concentrations of the order $Z$ of $1 \mu \mathrm{g} . / 100 \mathrm{ml}$. were detected. Since $0.2 \mathrm{ml}$. of thyroglobulin dilution was used in the test, the $\stackrel{\Phi}{\rightrightarrows}$ smallest quantity of thyroglobulin detected was of the order $0.002 \mu \mathrm{g}$. The eight active globulins were ${ }^{\mathbb{D}}$ prepared from sera of patients with Hashimoto's $\vec{\oplus}$ disease which were strongly positive in precipitin or tests against thyroid extracts and agglutinatedo tanned red cells coated with thyroglobulin in dilutions? of $1 / 1.000,000$ or more. Cells coated with globulin from two equally strongly positive Hashimoto sera were not agglutinated by thyroid or any other tissue $\bar{\Phi}$ extract. Of the other 33 exra which produced $\stackrel{\circ}{\Rightarrow}$ inactive globulin, 18 were from patients witho Hashimoto's disease or myxoedema (10 with medium or low titres of antibody in the tanned red cell test and eight negative), 10 were from patients without thyroid disease, and five were from luetics with a응 strongly positive Wassermann reaction. The cells: coated with active globulin were not agglutinated by extracts of normal brain, liver, kidney, spleen, heart, $\delta$ or blood cells in the presence of satisfactory controls. $₹$

Attempts to produce specifically agglutinable윽 cells by coating with whole immune serum were unsuccessful.

It was found that strongly positive sera which produced active globulin individually produced क active globulin when pooled, a property which allows $\tilde{O}$ use to be made of small remnants of specimens. N Mixtures of serum producing active and serum producing inactive globulin produced inactive globulin.

Mixtures of cells coated with active serum globulin $\stackrel{\oplus}{\rightarrow}$ and cells coated with thyroglobulin produced strong 0 agglutination patterns. These could not be certainly

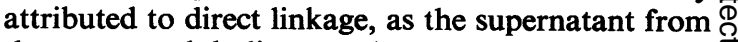
the serum globulin-coated cells agglutinated the $\mathbb{\mathbb { D }}$ thyroglobulin-coated cells (presumably because of 
elution of globulin from the cell surface by the normal rabbit serum-saline).

Cells coated with active and inactive globulin were agglutinated by rabbit anti-human serum.

Untanned cells did not take up the globulin and become agglutinable.

Cells coated with several concentrations of the most active globulin were titrated against serial dilutions of thyroid extract in a checkerboard pattern and the table shows the result. The higher concentrations of thyroid extract inhibit agglutination of the cells coated with all but the highest concentration of globulin, and the minimal concentration of extract causing inhibition of agglutination is proportional to the concentration of globulin used to coat the cells.

TABLE

Concentration of Coating Globulin

Reciprocal of Dilution of Thyroid Extract

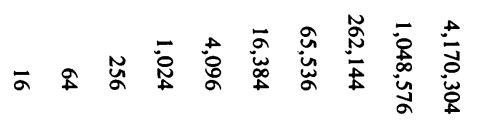

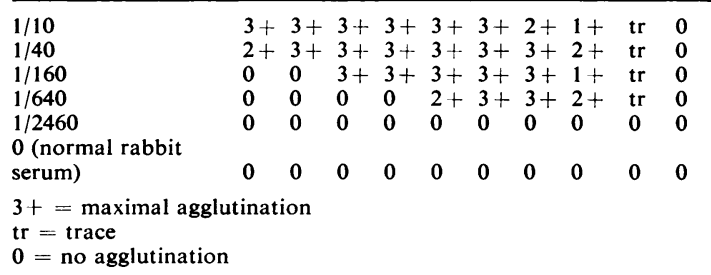

\section{DISCUSSION}

Van Loghem, Kresner, Coombs, and Roberts (1950) described the agglutination of antibody-coated cells by a solution of antigen in an experiment in which human group $\mathrm{O} \mathrm{cDE} / \mathrm{cde}$ red cells were sensitized with incomplete anti-D serum then exposed to antihuman globulin in the non-agglutinating 'prozone' concentration. After thorough washing to remove all traces of anti-human globulin from the supernatant, human gamma globulin was added and agglutination occurred. The antibody was not linked to the cell by a non-immunological bond but in other respects the mechanism, agglutination of antibody-coated particles by linkage through antigen, is similar to that postulated here. Richter et al. (1962) raised antibody in rabbits to bovine serum albumin, ovalbumin, and human gamma globulin, purified it by elution at $p \mathrm{H} 3.0$ from combination with an antigen polystyrene complex and coupled it to red cells with bis-diazotised benzidine by the method of Stavitsky and Arquila. The cells were specifically agglutinated by solutions of the cor- responding antigen in very low concentrations; high concentrations of antigen caused inhibition of agglutination in a prozone. These findings are confirmed by the results reported here. However, Richter et al. (1962) found that a gamma globulin fraction of the antiserum as opposed to purified antibody failed to render cells agglutinable by antigen solution and suggested that this might be due to the presence in the fraction of globulin other than specific antibody which coated enough of the cell surface to prevent optimal sensitization. If this is the case the globulin fractions of Hashimoto serum which rendered cells agglutinable by thyroid extract must have contained a very high ratio of specific antibody to other irrelevant globulin. Competition for the cell surface by irrelevant protein would also explain why globulin fractions of medium and low titre sera and whole high titre sera were ineffective as coating agents. If the hypothesis is correct, it follows that the use of a pure antibody as coating agent is a critical requirement for success and that globulin fractions can only be used when they approximate to pure antibody. A supporting analogy for this idea can be drawn from the observation that crude thyroid extract is unsuitable as a coating agent in the conventional tanned cell test for anti-thyroglobulin antibody, whereas thyroglobulin works well.

Technically, the experiments described here resemble Boyden's test in which protein antigen is applied to a tanned red blood cell and the complex agglutinated by an antiserum to the protein. Tanning of red cells is necessary for and must precede the uptake of the coating substance. The coated cells are unstable in saline, which must contain about $1 \%$ of rabbit serum to prevent spontaneous agglutination, while higher concentrations of protein usually depress or inhibit specific agglutination (Boyden, 1951; Boyden and Sorkin, 1955). The agglutinating substance (in this case the antigen) is effective in high dilution and need not be present in a pure state. From the specificity of the system, it seems reasonable to assume that the linkage is due to an antigen-antibody reaction.

Several biologically important substances have been assayed as antigen by immunological methods, for example, chorionic gonadotrophin in the urine by coated red cell agglutination-inhibition (Fulthorpe, Parke, Tovey, and Monckton, (1963) insulin in serum (Hales and Randle, 1963) and albumin in urine (Keen and Chlouverakis, 1963) by an isotope saturation method, and fibrinogen, gamma globulin and beta-lipoprotein in serum by latex-particle agglutination (Baxter Laboratories, Technical Information Bulletins Nos. 2, 3, and 9). The reverse tanned cell technique could in theory be used to assay any substance capable of acting as an antigen, provided 
that the relevant immune globulin can be isolated in a sufficiently pure state. When the antigen to be assayed is present as a component of a complex mixture the reverse version of the tanned cell test might be more easily applied than the inhibition version since the latter requires antigen in a pure state for coating the test cells.

My thanks are due to Professor G. A. Smart of the Department of Medicine, Professor C. A. Green of the Department of Bacteriology, and Professor A. G. Heppleston of the Department of Pathology, for facilities for work and materials; also to them and to the members of staff of their departments for helpful discussion and constructive criticism.

\section{REFERENCES}

Boyden, S. V. (1951). J. exp. Med., 93, 107.

and Sorkin, E. (1955). J. Immunol., 75, 15.

Derrien, Y., Michel, R., and Roche, J. (1948). Biochim. biophys. Acta (Amst.), $2,454$.

Fulthorpe, A. J., Parke, J. A. C., Tovey, J. E., and Monckton, J. C. C) (1963). Brit. med. J., 1, 1049.

Hales, C. N., and Randle, P. J. (1963). Biochem. J., 88, 137.

Keen, H., and Chlouverakis, C. (1963). Lancet, 2, 913.

Richter, M., Cua-Lim, F., and Rose, B. (1962). Biochem. biophys. res. Commun., 7, 241.

Van Loghem, J. J., Kresner, M., Coombs, R. R. A., and Roberts, G. F. (1950). Lancet, 2, 729.

\section{Broadsheets prepared by the Association of Clinical Pathologists}

The following broadsheets (new series) are published by the Association of Clinical Pathologists. They may be ob- $\vec{\omega}$ tained from Dr. R. B. H. Tierney, Pathological Laboratory, Boutport Street, Barnstaple, N. Devon. The prices include 은 postage, but airmail will be charged extra.

13 The Identification of Serotypes of Escherichia coli Associated with Infantile Gastro-enteritis. 1956. JOAN TAYLOR. 1s.

16 Preservation of Pathological Museum Specimens. 1957. L. W. PROGER. 1s.

17 Cultural Diagnosis of Whooping-cough. 1957. B. W. LACEY. 1s.

20 Investigation of Porphyrin/Porphyria. 1958 (reprinted 1962). C. RIMINGTON. $2 \mathrm{~s}$.

23 The Dried Disc Technique for Bacterial Sensitivity Tests. 1959. R. W. FAIRBROTHER and J. C. SHERRIS. 1s.

24 Safe Handling of Radioactive Tissues in the Laboratory and Post-mortem Room. 1959. R. C. CURRAN. 1s.

26 The Periodic Acid-Schiff Reaction. 1959. A. G. E. PEARSE. 1s.

28 Daily Fatty Acid Excretion. 1960. A. C. FRAZER. 2s.

29 The Preparation of Bone for Diagnostic Histology. 1960. D. H. Collins. 2s.

30 Control of Accuracy in Chemical Pathology. 1961. G. H. GRANT. $4 \mathrm{~s}$.

31 Investigation of Haemorrhagic States with Special Reference to Defects of Coagulation of the Blood. 1961. E. K. BLACKBURN. 4s.

32 Detection of Resistance to Streptomycin, P.A.S., and Isoniazid in Tubercle Bacilli. 1961. R. CRUICKSHANK and S. M. STEWART. $2 s$.

33 The Laboratory Detection of Abnormal Haemoglobins. 1961 (reprinted 1965). H. LEHMANN and J. A. M. AGER. 4s.

34 Titration of Antistreptolysin O. 1961. H. GOODER and R. E. O. WILliams. $2 s$.

35 The Estimation of Faecal 'Urobilinogen'. 1961. C. H. GRAY. 2 s.
36 Quantitative Determination of Porphobilinogen and Porphyrins in Urine and Faeces. 1961. C. RIMINGTON. 3s. 6d.

37 The Paper Electrophoresis of Serum and Urinary Proteins. 1961. G. FRANGLEN and N. H. MARTIN. 4s.

38 The Augmented Histamine Gastric Function Test. 1961. M. LUBRAN. 2s.

39 Investigation of Haemolytic Anaemia. 1961. J. G. SELWYN. 2s.

40 Short-term Preservation of Bacterial Cultures 1962. E. JOAN STOKES. $2 s$.

41 Serological Tests for Syphilis. 1962. A. E. WILKINson. 6 s.

42 The Determination of Glucose 6-Phosphate Dehydrogenase in Red Cells. 1962. T. A. J. PRANKERD. 2s.

43 Mycological Techniques. 1962. R. W. RIDDELL 3s. 6d.

44 The Laboratory Investigation of Catecholamine Secreting Tumours. 1963. M. SANDLER and C. R. J. RUTHVEN. $2 s$.

45 Diagnostic Test for Hereditary Galactosaemia. 1963. V. SCHWARTZ. 2s.

46 The Determination of Serum Iron and Total Iron Binding Capacity. 1963. A. JORDAN and D. A. O PODMORE. 2s.

47 Nuclear Sexing. 1964. B. LENNOX and w. M. DAVIDSON. 2s.

48 The Laboratory Investigation and Control of the Defibrination Syndrome. 1964. R. M. HARDISTY, G. I. C. INGRAM, and A. A. SHARP. 3s. 6d.

49 Rapid Diagnostic Section Technique. 1965. N. J. BROWN and A. T. SANDISON. 2s.

50 The Collecton, Preservation and Staining of Specimens for Gynæcological Cytology. 1965. ERICA WACHTEL. 4s. 